\title{
Racionero, Sandra; Ortega, Sara; García, Rocío; Flecha, Ramón. (2012). Aprendiendo contigo. Barcelona: Hipatia Editorial. ISBN: \\ 978-84-938226-3-7.
}

Aprendiendo contigo es un libro, que como sus autoras y autor lo definen, podría comprarse a un jardín de relatos que tras su lectura no nos dejará indiferentes.

A lo largo de siete capítulos, cada uno de ellos vinculado a un principio del Aprendizaje Dialógico, se presentan los relatos reales de niños y niñas, chicos y chicas que en su día a día en sus centros educativos están consiguiendo transformar sus vidas y su entorno.

Las autoras y autor poseen un reconocido background científico tanto a nivel teórico como práctico, de manera que avalan la calidad del contenido del libro y la utilidad del mismo para profesionales de la educación, familiares, y cualquier persona interesada en el poder de transformación que tiene la educación.

Los diferentes relatos del libro muestran cómo centros que están aplicando actuaciones educativas de éxito, están logrando superar el fracaso escolar en los colectivos de mayor riesgo de sufrir fracaso escolar y a su misma vez el propio centro se convierte en creador de sentido para las vidas de las personas que directa o indirectamente participan en él.

Como afirman las autoras y autor del libro, los colectivos más desfavorecidos ya no van a seguir aguantando que otros y otras decidan por ellos o a ser conejillos de indias de propuestas educativas sin base científica o basadas en concepciones del aprendizaje obsoletas que están llevando al fracaso. Y, mucho menos, en unos tiempos como los que corren en los que cada vez más personas tienen riesgo de sufrir exclusión social.

Desde la ilusión y la ciencia, ambos ingredientes presentes a lo largo de todo el libro, se están llevando a cabo actuaciones educativas de éxito que deben ser un referente para todos los centros educativos y profesionales de la educación. Sin necesidad de mayores recursos económicos es posible ofrecer oportunidades de éxito para todos los niños y niñas. Aprendiendo Contigo, nos muestra que sí es posible otra educación.

Carme Garcia Yeste. Departament de Pedagogia. Universitat Rovira i Virgili 